\title{
The dead line for oil and gas and implication for fossil resource prediction
}

\author{
Xiongqi Pang ${ }^{1,2}$, Chengzao Jia ${ }^{1,3}$, Kun Zhang ${ }^{2,4}$, Maowen $\mathbf{L i}^{5}$, Youwei Wang ${ }^{2,6}$, Junwen Peng ${ }^{7}$, \\ Boyuan $\mathrm{Li}^{2}$, and Junqing Chen ${ }^{1,2}$ \\ ${ }^{1}$ State Key Laboratory of Petroleum Resources and Prospecting, \\ China University of Petroleum, Beijing, 102249, China \\ ${ }^{2}$ College of Geosciences, China University of Petroleum, Beijing, 102249, China \\ ${ }^{3}$ Research Institute of Petroleum Exploration and Development, PetroChina, Beijing, 100083, China \\ ${ }^{4}$ Department of Earth Sciences, University College London, Gower Street, London, WC1E 6BT, UK \\ ${ }^{5}$ State Key Laboratory of Shale Oil and Gas Enrichment Mechanisms and Effective Development, \\ SINOPEC Exploration and Production Research Institute, Beijing, 100083, China \\ ${ }^{6}$ Department of Geosciences and Engineering, Delft University of Technology, \\ Stevinweg 1, 2628 CN Delft, the Netherlands \\ ${ }^{7}$ Bureau of Economic Geology, University of Texas at Austin, Austin, TX 78713, USA \\ Correspondence: Xiongqi Pang (pangxq@cup.edu.cn) and \\ Kun Zhang (zhangk.cupb@gmail.com, kun.zhang.19@ucl.ac.uk)
}

Received: 6 May 2019 - Discussion started: 19 June 2019

Revised: 4 February 2020 - Accepted: 6 February 2020 - Published: 12 March 2020

\begin{abstract}
Fossil fuel resources are invaluable to economic growth and social development. Understanding the formation and distribution of fossil fuel resources is critical for the search and exploration of them. Until now, the vertical distribution depth of fossil fuel resources has not been confirmed due to different understandings of their origins and the substantial variation in reservoir depths from basin to basin. Geological and geochemical data of 13634 source rock samples from 1286 exploration wells in six representative petroliferous basins were examined to identify the maximum burial depth of active source rocks in each basin, which is referred to in this study as the active source rock depth limit (ASDL). Beyond the ASDL, source rocks no longer generate or expel hydrocarbons and become inactive. Therefore, the ASDL also sets the maximum depth for fossil fuel resources. The ASDLs of basins around the world are found to range from 3000 to $16000 \mathrm{~m}$, while the thermal maturities (Ro) of source rocks at the ASDLs are almost the same, with Ro $\approx 3.5 \pm 0.5 \%$. The Ro of $3.5 \%$ can be regarded as a general criterion to identify ASDLs. High heat flow and more oil-prone kerogen are associated with shallow ASDLs. In addition, tectonic uplift of source rocks can significantly affect ASDLs; 21.6 billion tons of reserves in six representative basins in China and 52926 documented oil and gas reservoirs in 1186 basins around the world are all located above ASDLs, demonstrating the universal presence of ASDLs in petroliferous basins and their control on the vertical distribution of fossil fuel resources. The data used in this study are deposited in the repository of the PANGAEA database at: https://doi.org/10.1594/PANGAEA.900865 (Pang et al., 2019).
\end{abstract}




\section{Introduction}

Fossil fuel resources, including coal and conventional and unconventional hydrocarbons, account for $85.5 \%$ of the world total energy consumption in 2016 (B.P. Global, 2017). Because of their indispensable role in the world economy, some research has been done on fossil fuels in the past few decades, including characterizing and explaining their spatial distribution in various types of sedimentary basins (Tissot and Welte, 1978; Wang et al., 1997; Gautier et al., 2009) and their temporal distribution over the past 1.6 billion years of geological history (Wang et al., 2016). However, the vertical distribution of fossil fuel resources, especially the maximum preservation depth, remains ambiguous because of different understandings of the fossil fuel resource origins and the great variations in the depths from basin to basin (Kennedy et al., 2002; Peters et al., 2005; Pang et al., 2015).

As global demand for energy keeps rising, fossil fuel exploration is rapidly expanding to more challenging and deep regions of the Earth (Dyman et al., 2002). Currently, the deepest commercial hydrocarbon reservoir worldwide is located in the basin of the Gulf of Mexico, with a depth of $11945 \mathrm{~m}$ (including water depth; Transocean, 2009). In China, deep $(>4500 \mathrm{~m})$ and ultra-deep $(>6000 \mathrm{~m})$ oil and gas reservoirs are mainly found in the Tarim Basin, where the amount of deep oil and gas reserves is estimated to account for more than $90 \%$ of the total proven reserves (Pang et al., 2015). In order to boost oil and gas supply to support fast economic growth, China initiated research programs developing $10000 \mathrm{~m}$ scientific drilling rigs and funded the National Basic Research Program (973 Program) to better understand the deep hydrocarbon accumulations of basins (Jia et al., 2016). One major challenge for deep oil and gas exploration comes from the significant variation in reservoir depths in different basins and the uncertainty it poses to oil and gas resource assessment. In some basins, dry layers, target strata containing no oil or gas, are prevalent at a depth of $4500 \mathrm{~m}$ or less, whereas in some other basins, the maximum burial depth for oil and gas accumulation is predicted to be more than $10000 \mathrm{~m}$. To date, the maximum depth to which fossil fuels can be formed and preserved in the Earth's crust remains unresolved. Some research supporting the abiogenic petroleum origin asserts that the maximum depth of hydrocarbon occurrence is much deeper than the maximum depth of petroliferous basins (Gold, 1993; Kenney et al., 2002). Growing evidence, however, supports that oil and gas are of biogenic origin and suggests that the maximum depth of oil and gas reservoirs is critically controlled by the depth of active source rocks which generate and expel oil and gas in sedimentary basins (Tissot and Welte, 1978; Durand, 1980; Hunt, 1996).

To solve this mystery and to understand hydrocarbon generation and accumulation processes, this study selected six representative petroliferous basins in China, which have the largest areas, the largest proven oil and gas reserves, and the highest exploration degrees (Fig. 1; Table 1), to identify the maximum depth of fossil fuel resources in each basin and investigate factors leading to the variation in the maximum depth from one basin to another. This study did not take the abiogenic petroleum origin into account for the reason that the genetic relationship between petroleum and organic matter in source rocks are proved and widely accepted (Magoon and Dow, 1994; Peters et al., 2005). Besides this, no commercial petroleum reservoirs of abiogenic origins have been discovered to date (Kenney et al., 2002; Glasby, 2006; Höök et al., 2010; Selley and Sonnenberg, 2014). In this study, geological and geochemical data of 13634 source rock samples from 1286 exploration wells in six basins were examined. The maximum depths for the formation and occurrence of fossil fuel resources in these basins were determined. Major geological factors influencing the maximum depths of active source rocks were analyzed, and their control on the distribution of fossil fuel resources was discussed.

\section{Materials and methods}

\subsection{Study sites and data collection}

We mainly examined source rock vertical distributions in six representative basins in China, including the Songliao Basin and the Bohai Bay Basin in eastern China, the Sichuan Basin and the Ordos Basin in central China, and the Tarim Basin and the Junggar Basin in western China. For each basin, we utilized at least four different indicators detailed in the Sect. 2.2 to determine the active source rock depth limit (ASDL). The data were obtained from PetroChina and Sinopec and are available through the PANGAEA database at: https://doi.org/10.1594/PANGAEA.900865 (Pang et al., 2019). We also investigated the relationship between ASDLs and the distributions of 52926 reservoirs in 1186 basins around the world according to the database of IHS (2010) to verify its universality.

\subsection{Characterization of ASDLs}

Active source rocks are sedimentary rocks rich in organic matter and capable of generating hydrocarbons. In the evolution history of a basin that spans over millions of years, source rocks are activated and produce hydrocarbons at certain conditions, such as the generally regarded threshold temperature of $60^{\circ} \mathrm{C}$ (Tissot and Welte, 1978; Peters and Cassa, 1994). With a further increase in burial depth of the source rocks, the potential amount of hydrocarbons that can be produced and expelled from the source rocks decreases and eventually approaches zero. The active source rock depth limit (ASDL) is defined as the maximum burial depth of active source rocks beyond which the source rocks no longer generate or expel hydrocarbons and become inactive. In addition to the burial depth, the ASDL can also be character- 
Table 1. Geological and geochemical characteristics of the main source rocks from the six representative petroliferous basins in China.

\begin{tabular}{|c|c|c|c|c|c|c|c|c|c|}
\hline \multirow[b]{2}{*}{$\begin{array}{l}\text { Basin } \\
\text { location }\end{array}$} & \multirow[b]{2}{*}{$\begin{array}{l}\text { Basin } \\
\text { name }\end{array}$} & \multicolumn{4}{|c|}{ Basic features of representative basins } & \multicolumn{4}{|c|}{ Features of main source rocks } \\
\hline & & $\begin{array}{l}\text { Basin } \\
\text { type }\end{array}$ & $\begin{array}{r}\text { Basin area } \\
\left(10^{4} \mathrm{~km}^{2}\right), \\
\text { maximum } \\
\text { depth } \\
(\mathrm{m})\end{array}$ & $\begin{array}{r}\text { Heat flow } \\
\left(\mathrm{mW} \mathrm{m}^{-2}\right), \\
\text { geothermal } \\
\text { gradient } \\
\left({ }^{\circ} \mathrm{C} \text { per } 100 \mathrm{~m}\right)\end{array}$ & $\begin{array}{r}\text { National } \\
\text { ranking } \\
\text { of } \\
\text { reserves, } \\
\text { resources }\end{array}$ & $\begin{array}{l}\text { Age and } \\
\text { lithology }\end{array}$ & $\begin{array}{r}\text { Organic } \\
\text { matter } \\
\text { abundance } \\
(\mathrm{TOC} ; \%)\end{array}$ & $\begin{array}{l}\text { Organic } \\
\text { matter } \\
\text { type }\end{array}$ & $\begin{array}{r}\text { Maximum } \\
\text { measured } \\
\text { maturity } \\
(\text { Ro; \%) }\end{array}$ \\
\hline \multirow{2}{*}{$\begin{array}{l}\text { Western } \\
\text { China }\end{array}$} & $\begin{array}{l}\text { Tarim } \\
\text { Basin }\end{array}$ & $\begin{array}{l}\text { Complex } \\
\text { superimposed } \\
\text { basin }\end{array}$ & $\begin{array}{r}53 \\
9100\end{array}$ & $\begin{array}{r}43.0 \\
2.00\end{array}$ & 5,2 & $\begin{array}{l}\text { Cambrian- } \\
\text { Ordovician } \\
\text { carbonate }\end{array}$ & $0.2-5.0$ & I-II & $3.7^{*}$ \\
\hline & $\begin{array}{l}\text { Junggar } \\
\text { Basin }\end{array}$ & $\begin{array}{l}\text { Complex } \\
\text { superimposed } \\
\text { basin }\end{array}$ & $\begin{array}{r}38 \\
8900\end{array}$ & $\begin{array}{r}45.0 \\
2.30\end{array}$ & 4,5 & $\begin{array}{l}\text { Permian } \\
\text { shale }\end{array}$ & $0.5-3.5$ & I-II & 2.5 \\
\hline \multirow{2}{*}{$\begin{array}{l}\text { Central } \\
\text { China }\end{array}$} & $\begin{array}{l}\text { Sichuan } \\
\text { Basin }\end{array}$ & $\begin{array}{l}\text { Superimposed } \\
\text { basin }\end{array}$ & $\begin{array}{r}26 \\
7800\end{array}$ & $\begin{array}{r}58.3 \\
2.35\end{array}$ & 6,6 & $\begin{array}{l}\text { Triassic } \\
\text { shale }\end{array}$ & $1.0-3.0$ & II-III & 3.2 \\
\hline & $\begin{array}{l}\text { Ordos } \\
\text { Basin }\end{array}$ & $\begin{array}{l}\text { Superimposed } \\
\text { basin }\end{array}$ & $\begin{array}{r}37 \\
6100\end{array}$ & $\begin{array}{r}62.9 \\
2.75\end{array}$ & 3,4 & $\begin{array}{l}\text { Carboniferous- } \\
\text { Permian } \\
\text { coal strata }\end{array}$ & $2.0-6.5$ & II-III & 2.8 \\
\hline \multirow{2}{*}{$\begin{array}{l}\text { Eastern } \\
\text { China }\end{array}$} & $\begin{array}{l}\text { Bohai Bay } \\
\text { Basin }\end{array}$ & $\begin{array}{l}\text { Fault } \\
\text { depression } \\
\text { basin }\end{array}$ & $\begin{array}{r}20 \\
5800\end{array}$ & $\begin{array}{r}64.8 \\
3.20\end{array}$ & 1,1 & $\begin{array}{l}\text { Paleogene } \\
\text { shale }\end{array}$ & $1.0-4.0$ & I-II & 2.7 \\
\hline & $\begin{array}{l}\text { Songliao } \\
\text { Basin }\end{array}$ & $\begin{array}{l}\text { Rift-fault } \\
\text { basin }\end{array}$ & $\begin{array}{r}26 \\
5400\end{array}$ & $\begin{array}{r}69.0 \\
4.00\end{array}$ & 2,3 & $\begin{array}{l}\text { Jurassic- } \\
\text { Cretaceous } \\
\text { shale }\end{array}$ & $1.0-4.0$ & I-II & 3.6 \\
\hline
\end{tabular}

$* \mathrm{Ro}=0.618 \cdot \mathrm{Ro}^{\mathrm{B}}+0.40, \mathrm{Ro}^{\mathrm{B}}$ is solid bitumen reflectance $(\%)$.

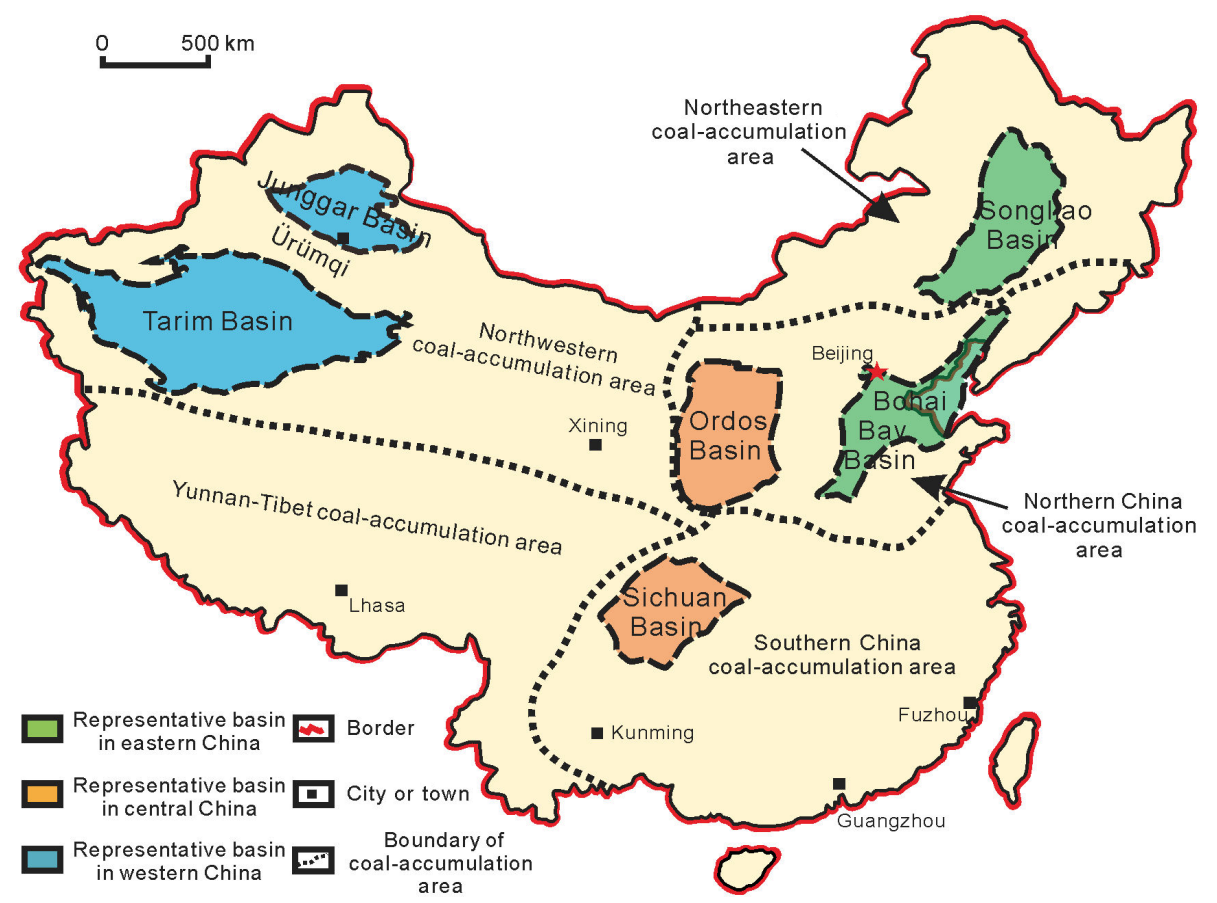

Figure 1. Location of the six representative petroliferous basins and five coal-accumulation areas in China. The studied petroliferous basins, plotted on the China mainland, are pigmented with different colors according to their locations in China. The five coal-accumulation areas, bounded by large geological structural belts, are mapped according to Zhu (2011). 
ized by other physical parameters of source rocks, such as the thermal maturity.

The potential amount of hydrocarbons that can be further generated from a source rock sample cannot be directly measured but can be evaluated based on many experimentally measurable parameters, such as the atomic ratios of hydrogen to carbon $(\mathrm{H} / \mathrm{C})$ and oxygen to carbon $(\mathrm{O} / \mathrm{C})$ of the remaining organic matter in the sample. The generation of oil and gas from organic matter is the process of condensation of the aromatic nuclei that enriches carbon by deoxygenation and dehydrogenation. The process can be experimentally studied by measuring the decrease in the $\mathrm{H} / \mathrm{C}$ and $\mathrm{O} / \mathrm{C}$ atomic ratios (Tissot et al., 1974). In theory, organic matter in source rocks eventually evolves into graphite with increasing thermal maturity and their atomic $\mathrm{H} / \mathrm{C}$ and $\mathrm{O} / \mathrm{C}$ ratios drop to zero. This indicates that the active source rocks no longer produce hydrocarbons and thus reach the ASDL.

Rock-Eval pyrolysis parameters can also be utilized to identify the ASDL such as the hydrocarbon generation potential index (" $S_{1}+S_{2}$ " / TOC). " $S_{1}$ " is the amount of hydrocarbons released from a source rock sample when it is heated from room temperature to $300^{\circ} \mathrm{C}$, and " $S_{2}$ " is the amount released from 300 to $600^{\circ} \mathrm{C}$. TOC is the measured total organic carbon in the source rock sample (Espitalie et al., 1985). The concept of the hydrocarbon generation potential index was proposed by Zhou and Pang (2002). Pang et al. (2005) utilized the index to measure the quantity of hydrocarbons that can be generated from a single unit weight of organic carbon. The index generally increases with increasing burial depth when the thermal maturity is low and then decreases with increasingly higher burial depth or thermal maturity. The turning point of the hydrocarbon generation potential index corresponds to the hydrocarbon expulsion threshold (HET), which was proposed by Pang et al. (1997). The HET represents when hydrocarbons start migrating out of source rocks to surrounding reservoirs. As the expulsion continues, the hydrocarbon generation potential index gradually decreases. When the index approaches zero, source rocks can no longer expel hydrocarbons and reach the ASDL. Along with the evolution of the hydrocarbon generation potential index, the hydrocarbon expulsion ratio $\left(Q_{\mathrm{e}}\right)$, hydrocarbon expulsion rate $\left(V_{\mathrm{e}}\right)$, and hydrocarbon expulsion efficiency $\left(K_{\mathrm{e}}\right)$ of the source rocks also evolve with thermal maturity. $Q_{\text {e }}$ represents the amounts of hydrocarbons expelled from a unit weight of organic carbon. $V_{\mathrm{e}}$ represents the hydrocarbons expelled from a unit weight of organic carbon when the burial depth increases by $100 \mathrm{~m}$. $K_{\mathrm{e}}$ represents the ratio of the cumulative amount of hydrocarbons expelled from source rocks to the cumulative amounts of hydrocarbons generated. When source rocks reach the ASDL, $Q_{\mathrm{e}}$ and $K_{\mathrm{e}}$ approach constant values and $V_{\mathrm{e}}$ approaches the value of zero.

Hydrocarbon generation is the transformation of original organic matter, also referred to as kerogen, into transitional compounds and finally to hydrocarbons (Behar et al., 2006). When the amount of transitional compounds or residual hy- drocarbons (" $S_{1}$ " or " $A$ ") decreases to zero, the hydrocarbon generation potential is also exhausted. Experimentally, " $A$ " is the amount of hydrocarbons extracted by a chloroform solution from a source rock sample. Because some nonhydrocarbon compounds are also extracted, " $A$ " is generally larger than " $S_{1}$ ". The residual hydrocarbon content index (" $S_{1}$ " / TOC or " $A$ " / TOC), which represents the quantity of hydrocarbons retained per unit weight of organic carbon, can therefore be utilized to indicate the ASDL. Previous studies (Zhou and Pang, 2002; Pang et al., 2005) indicate that source rocks reach HET when the residual hydrocarbon content index reaches its maximum value. After that, the index begins to decrease. The source rocks finally become inactive (i.e., reach the ASDL) when the residual hydrocarbon content index decreases to a minimum value. In summary, the parameters listed in the section, including $\mathrm{H} / \mathrm{C}, \mathrm{O} / \mathrm{C}$, " $S_{1}+S_{2}$ " / TOC, " $S_{1}$ " / TOC, " $A$ " / TOC, $V_{\mathrm{e}}$, and $K_{\mathrm{e}}$, all trend as a function of source rock burial depth $(D)$ or thermal maturity (Ro). The ASDL can thus be represented as the critical values of $D$ or Ro when the indices of $\mathrm{H} / \mathrm{C}, \mathrm{O} / \mathrm{C}$, " $S_{1}+S_{2}$ " / TOC, " $S_{1}$ " / TOC, " $A$ " / TOC, and $V_{\mathrm{e}}$ approach zero or when $K_{\mathrm{e}}$ approaches a constant value.

\section{Results and discussions}

\subsection{ASDLs in the six representative basins}

The ASDLs of the six representative basins were characterized. The Junggar Basin located in western China is used as an example to illustrate the process of characterization (Fig. 2). The same methods were applied to study the other five basins, and the results are shown in Figs. S1-S5 in the Supplement and Table 2. The hydrocarbon formation and accumulation in the Junggar Basin are mainly controlled by the Permian petroleum system (Wang et al., 2001). Previous geochemical and sedimentological data demonstrate that the source rocks are mainly Permian shales and that the main reservoirs are the clastic rocks in the Permian, the Triassic, and the Jurassic formations capped by the Upper Triassic, the Lower Jurassic, and the Lower Cretaceous mudstones, respectively (Cao et al., 2005). A few Carboniferous volcanic reservoirs are found distributed in structural highs near fault zones and unconformities, and the hydrocarbons in these reservoirs are also primarily derived from the Permian shales (Chen et al., 2016; Wang et al., 2018). According to the analyses of fluid inclusions and basin modeling, the Permian source rocks have started generating hydrocarbons since the Middle Permian-Late Permian due to a rifting-process-related high heat flow, and the main hydrocarbon accumulation period spanned from the Triassic to the Paleogene for the whole basin (Wang et al., 2001; Cao et al., 2005). Petroleum systems in the other five basins were studied by other researchers (Zhou and Littke, 1999; Xiao et al., 2005; Wu et al., 2008; Ping et al., 2017; Zhu et al., 2018). 
Table 2. Comparison of active source rock depth limits in the six petroliferous basins of China.

\begin{tabular}{|c|c|c|c|c|c|c|c|c|}
\hline \multicolumn{2}{|c|}{$\begin{array}{l}\text { Research methods and related indicators for } \\
\text { identifying ASDLs }\end{array}$} & \multicolumn{7}{|c|}{$\begin{array}{l}\text { The maximum burial depth }(D ; \mathrm{m}) \text { and thermal maturity }(\mathrm{Ro} ; \%) \\
\text { corresponding to active source rock depth limits }\end{array}$} \\
\hline & & \multirow{2}{*}{$\begin{array}{r}\text { Tarim } \\
\text { Basin } \\
8970 / 3.5 \\
9050 / 3.6\end{array}$} & \multirow{2}{*}{$\begin{array}{r}\text { Junggar } \\
\text { Basin } \\
8350 / 3.2 \\
8450 / 3.2\end{array}$} & \multirow{2}{*}{$\begin{array}{r}\text { Sichuan } \\
\text { Basin } \\
- \\
-\end{array}$} & \multirow{2}{*}{$\begin{array}{r}\text { Ordos } \\
\text { Basin } \\
- \\
-\end{array}$} & \multirow{2}{*}{$\begin{array}{r}\begin{array}{r}\text { Bohai } \\
\text { Bay } \\
\text { Basin }\end{array} \\
5800 / 3.5 \\
5740 / 3.4\end{array}$} & \multirow{2}{*}{$\begin{array}{r}\begin{array}{r}\text { Songliao } \\
\text { Basin }\end{array} \\
5280 / 3.6 \\
5280 / 3.6\end{array}$} & $\begin{array}{l}\text { The average } \\
\text { values for } \\
\text { six basins }\end{array}$ \\
\hline $\begin{array}{l}\text { The variation in element } \\
\text { composition }\end{array}$ & $\begin{array}{l}\mathrm{H} / \mathrm{C} \\
\mathrm{O} / \mathrm{C}\end{array}$ & & & & & & & $\begin{array}{l}7100 / 3.4 \\
7130 / 3.4\end{array}$ \\
\hline $\begin{array}{l}\text { The variation in } \\
\text { hydrocarbon generation } \\
\text { and expulsion }\end{array}$ & $\begin{array}{l}\text { " } S_{1}+S_{2} " / \text { TOC } \\
V_{\mathrm{e}}\end{array}$ & $\begin{array}{l}9300 / 3.8 \\
9210 / 3.8\end{array}$ & $\begin{array}{l}8200 / 3.0 \\
8200 / 3.0\end{array}$ & $\begin{array}{l}7700 / 3.8 \\
7660 / 3.7\end{array}$ & $\begin{array}{l}6600 / 3.4 \\
6520 / 3.4\end{array}$ & $\begin{array}{l}5900 / 3.3 \\
5700 / 3.3\end{array}$ & $\begin{array}{l}5400 / 3.9 \\
5500 / 4.0\end{array}$ & $\begin{array}{l}7183 / 3.5 \\
7115 / 3.5\end{array}$ \\
\hline \multicolumn{2}{|c|}{$\begin{array}{l}\text { The average values obtained from different } \\
\text { methods in each basin }\end{array}$} & $9145 / 3.7$ & $8168 / 3.1$ & $7670 / 3.7$ & $6518 / 3.4$ & $5698 / 3.3$ & $5348 / 3.8$ & $7094 / 3.5$ \\
\hline
\end{tabular}

(a)

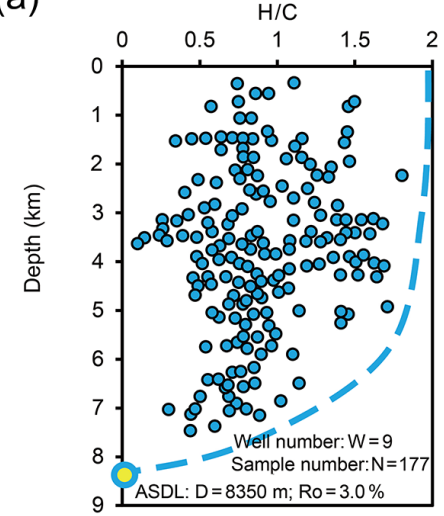

(b)

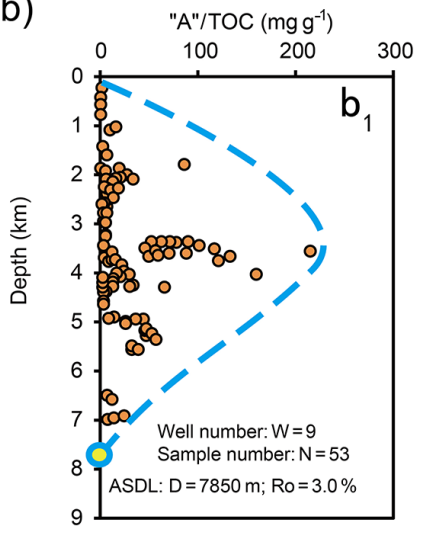

"S,"/TOC $\left(\mathrm{mg} \mathrm{g}^{-1}\right)$

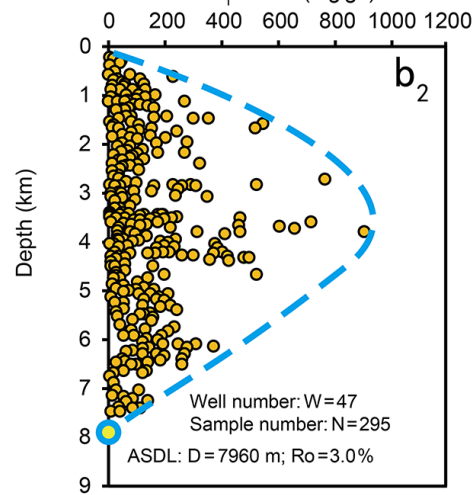

(c)

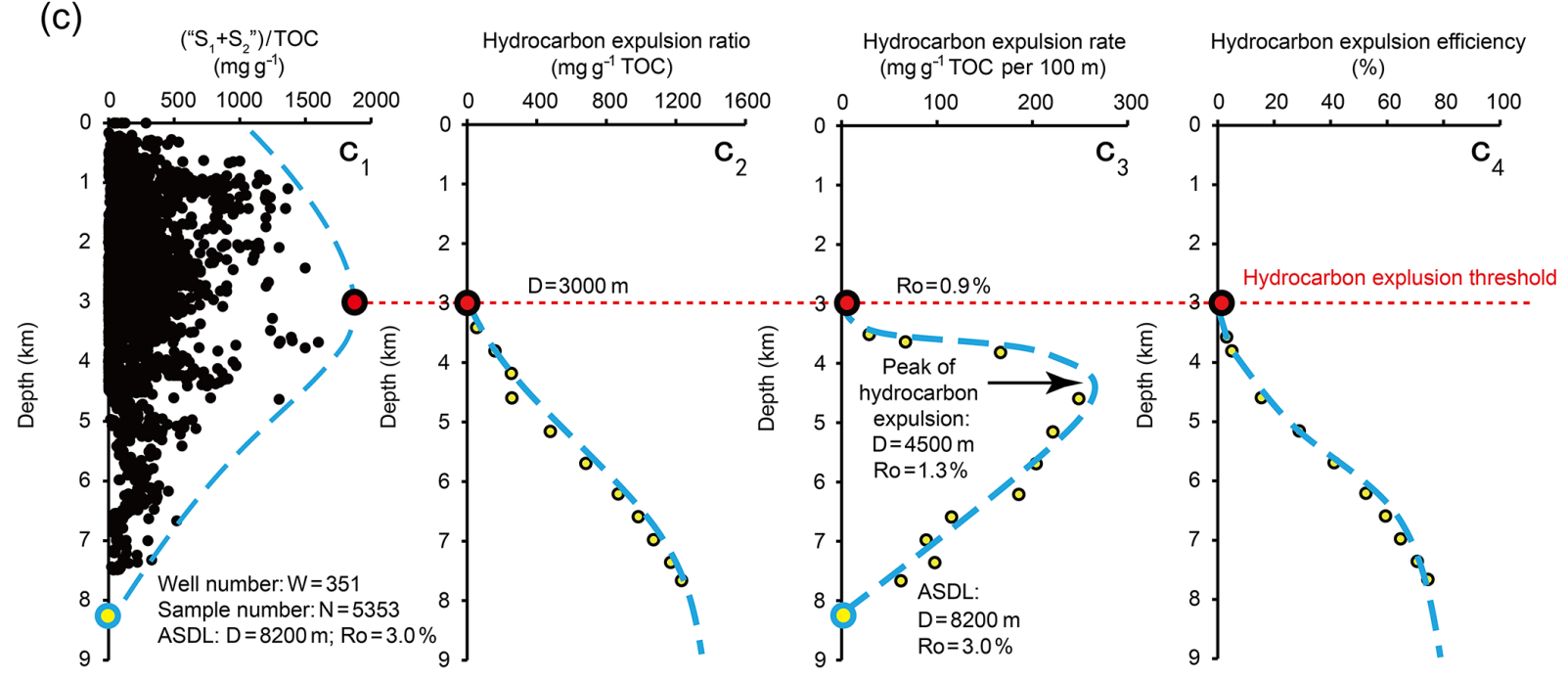

Figure 2. Identification of ASDL in the Junggar Basin using different indicators, including the variation in $\mathrm{H} / \mathrm{C}$ ratios (a), residual hydrocarbon amounts (b), " $\mathrm{S}_{1}+\mathrm{S}_{2}$ " / TOC (c1), $Q_{\mathrm{e}}(\mathrm{c} 2), V_{\mathrm{e}}(\mathrm{c} 3)$, and $K_{\mathrm{e}}$ (c4) versus depth. 
In Sect. 2 ("Materials and methods"), we provided theoretical threshold values of different geochemical parameters or indices to identify the ASDL. In practice, envelope lines enclosing all sample data points are utilized to show the overall trends of how these parameters change with increasing burial depth or thermal maturity. The interceptions of the envelope lines with these threshold values represent source rocks reaching ASDLs. This envelope method has been widely and successfully employed in a variety of basins in China, and numerous studies containing different geochemical data and mathematical models have been published (Zhou and Pang, 2002; Pang et al., 2004; Jiang et al., 2016; Peng et al., 2018). It is found that the profiles of hydrocarbon generation potential index, $V_{\mathrm{e}}$, and residual hydrocarbons are overall bell-shaped, although details can vary depending on the source rock types (e.g., different lithologies and organic matter types). On the other hand, some uncertainties may exist in the envelope method due to the lack of data from ultra-deep wells. In this case, the ASDLs can be identified by extrapolating the profiles according to the variation trends established based on the available data at different burial depths or thermal maturities. The envelope lines employed in this study are guided by well-established models and trends derived from actual geochemical data.

Figure 2a shows atomic $\mathrm{H} / \mathrm{C}$ ratios of source rock samples from the Permian shales plotted against burial depth. The average atomic $\mathrm{H} / \mathrm{C}$ ratio decreases sharply at a depth of about $6000 \mathrm{~m}$, beyond which there are no samples with atomic $\mathrm{H} / \mathrm{C}$ ratios greater than 1.5. The intercept of the dashed line on the vertical axis marks the ASDL, which corresponds to $D \approx 8350 \mathrm{~m}$ and $\mathrm{Ro} \approx 3.0 \%$. Figure $2 \mathrm{~b}$ shows the variation in residual hydrocarbon amounts in source rock samples, represented by " $A$ " / TOC or " $S_{1}$ " / TOC, with burial depth. Initially, both the mean and the variance in the residual hydrocarbon amounts increase with depth because hydrocarbons are generated but not yet expelled out of the source rocks. The mean reached the maximum at the depth of 3500 to $4000 \mathrm{~m}$ or at Ro $\approx 1.0 \%$, which is the HET. With a further increase in depth, the amount of residual hydrocarbon starts decreasing and eventually reaches zero at a depth of $7850-7960 \mathrm{~m}$ and a corresponding Ro of $3.0 \%$, indicating the ASDL. Figure $2 \mathrm{c}$ shows the change of the hydrocarbon generation potential index ((" $S_{1}+S_{2}$ ”) / TOC), hydrocarbon expulsion ratio $\left(Q_{\mathrm{e}}\right)$, hydrocarbon expulsion rate $\left(V_{\mathrm{e}}\right)$, and hydrocarbon expulsion efficiency $\left(K_{\mathrm{e}}\right)$ of the source rock samples with increasing burial depth. These results indicate an ASDL of $8200 \mathrm{~m}$, with Ro of $3.0 \%$, in good agreement with the ASDL values obtained in Fig. 2a and b. In addition, the HET is determined to be a $D$ of $3000 \mathrm{~m}$ and Ro of $0.9 \%$, and the hydrocarbon expulsion peak occurs at a $D$ of $4500 \mathrm{~m}$ and Ro of $1.3 \%$.

According to the ASDLs identified for the six representative basins (Table 2), three general conclusions on the ASDL can be drawn. First, for the same basin, the ASDLs derived from the six geochemical indices are the same or very close in value. For the Junggar Basin, the derived ASDLs vary from 7850 to $8450 \mathrm{~m}$, with an average value of $8168 \mathrm{~m}$ and a deviation of $7.6 \%$. Second, ASDLs in different basins can be very different. ASDLs of the six basins range between 5280 and $9300 \mathrm{~m}$, with an average value of $7094 \mathrm{~m}$ and a deviation $>76.1 \%$. Third, for all the ASDLs of the six basins, the corresponding thermal maturities (Ro) have much smaller variation than the depths. Ro values vary from $3.0 \%$ in the Junggar Basin to $4.0 \%$ in the Songliao Basin, with an average of $3.5 \%$ among the six basins and a deviation of $33.3 \%$, much smaller than the $76.1 \%$ deviation of the depths. This implies that the ASDL is mainly controlled by the thermal maturity of source rocks. The average thermal maturity level of $3.5 \%$ derived in this study can be regarded as the identification criterion for the ASDL in general geological settings.

\subsection{Major factors controlling ASDLs and their effects}

\subsubsection{Organic matter type}

Original organic matter (or kerogen) in source rocks is generally classified into three types based on its origin (Tissot et al., 1974; Peters and Cassa, 1994). The three types have different organic element compositions and different pyrolytic parameters and therefore have different hydrocarbon generation potentials. The hydrocarbon generation potential indices of different type source rock samples from the representative basins are plotted in Fig. 3. The dashed curves enveloping all the sample data points indicate the varying trends of hydrocarbon generation potential of source rocks with different organic matter types. The trends with thermal maturity (Ro) are very similar for all three organic matter types: the index first increases with increasing Ro and then decreases after source rocks reach HET. Source rocks with type I (oilprone), type II, and type III (gas-prone) kerogens reach ASDLs at Ro values of 3.0, 3.5, and $4.0 \%$, respectively. This indicates that oil-prone source rocks are more likely to reach the ASDL and stop generating and expelling hydrocarbons at a shallower burial depth than the other two types of source rocks under similar geological conditions.

\subsubsection{Heat flow and geothermal gradient}

ASDLs are shallow in petroliferous basins with high heat flow and a high geothermal gradient. The ASDLs in the six basins span from 5400 to $9300 \mathrm{~m}$, as determined from hydrocarbon generation potential index (Fig. 4). The basins in western China have low heat flow and a low geothermal gradient $\left(1.5-2.8^{\circ} \mathrm{C}\right.$ per $\left.100 \mathrm{~m}\right)$ and thus have the deepest ASDLs, ranging from 8200 to $9300 \mathrm{~m}$. The basins in eastern China are of high heat flow and a high geothermal gradient $\left(3.0-4.2^{\circ} \mathrm{C}\right.$ per $\left.100 \mathrm{~m}\right)$ and then have the shallowest ASDLs, ranging from 5400 to $5900 \mathrm{~m}$. The basins in central China are moderate in terms of a heat flow and geothermal gradient, and the depths of ASDLs vary from 6600 to $7700 \mathrm{~m}$. In addition, the source rock burial depths corresponding to 
(a)

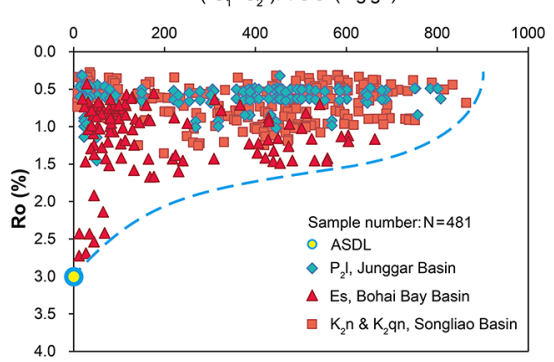

(b)

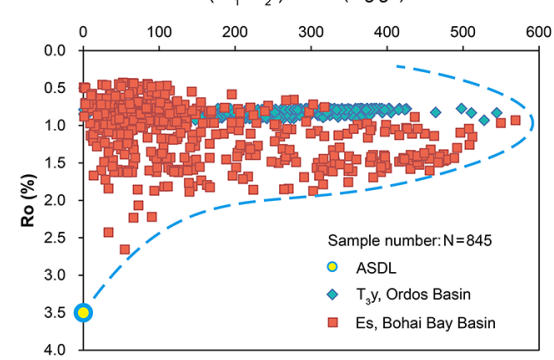

(c)

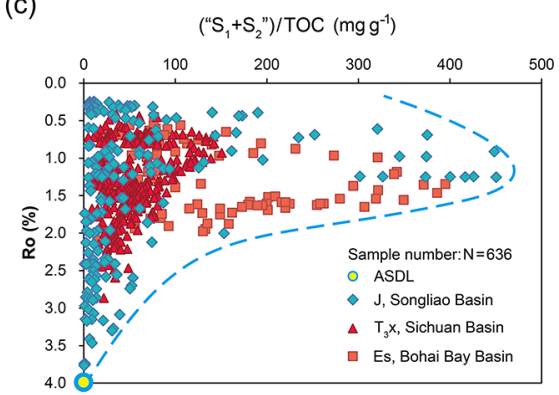

Figure 3. Effects of kerogen types on ASDLs represented by thermal maturity (Ro). From left to right are three plots of hydrocarbon generation potential index versus Ro for source rocks of type I (a), type II (b), and type III (c).

(a)

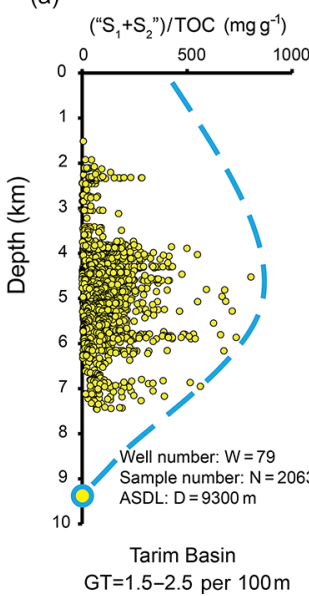

(b)

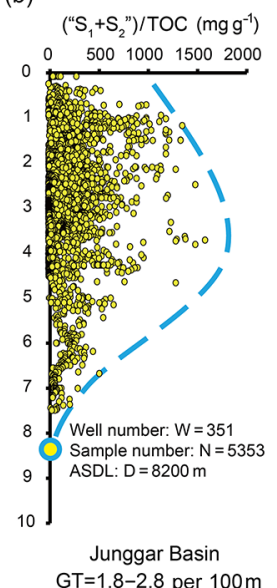

(c)

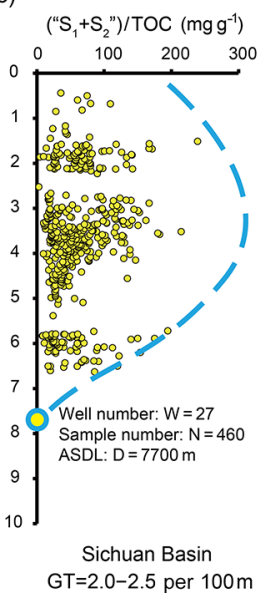

(d)

$\left(\right.$ “ $\mathrm{S}_{1}+\mathrm{S}_{2}$ ) $) / \mathrm{TOC}\left(\mathrm{mg} \mathrm{g}^{-1}\right)$

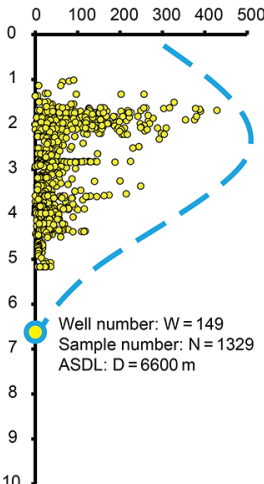

Ordos Basin (e)

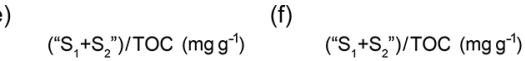

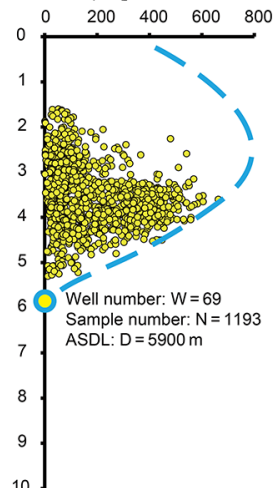

Bohai Bay Basin $\mathrm{GT}=3.0-3.8$ per $100 \mathrm{~m}$

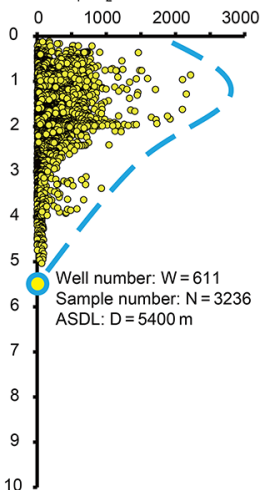

Songliao Basin $\mathrm{GT}=3.8-4.2$ per $100 \mathrm{~m}$

Figure 4. Variation in ASDLs in the six representative basins due to different heat flows. The ASDLs of different petroliferous basins are characterized by hydrocarbon generation potential index (represented by " $S_{1}+S_{2}$ " / TOC). From left to right, the heat flow (geothermal gradients) of each basin gradually increases, while the corresponding ASDL becomes shallower. (a) Tarim Basin. (b) Junggar Basin. (c) Sichuan Basin. (d) Ordos Basin. (e) Bohai Bay Basin. (f) Songliao Basin.

HETs vary similarly: high heat flow and a high geothermal gradient lead to shallow HETs (Fig. 4).

\subsubsection{Tectonic movement, stratigraphic age, and other factors}

The ASDL is also influenced by other two important factors, i.e., tectonic uplift and stratigraphic age of source rocks. As previously stated, the ASDL is better characterized by thermal maturity than by depth, and Ro $=3.5 \%$ is regarded as a general threshold for the ASDL in common geological settings. However, the corresponding depth of the ASDL for different source rock layers is highly variable. Due to the irreversible nature of vitrinite reflectance (Hayes, 1991; Peters et al., 2018), the depth of the ASDL for source rocks that were historically uplifted after reaching the original ASDL is shallower compared with younger source rocks that were not uplifted. Sichuan Basin, which experienced several stages of tectonic uplift in the geological history and its ASDL, was greatly affected by these events. For example, the Ro of the upper Triassic source rocks is about $1.0 \%$ at the depth of $\sim 2000 \mathrm{~m}$ in the southern Sichuan Basin (Zhu et al., 2016). At the same burial depth, however, the Ro of the lower Triassic source rocks can reach $2.0 \%$ (Zhu et al., 2016). Therefore, tectonic uplift and stratigraphic age of source rocks can have a significant effect on the corresponding depth of the ASDL.

In addition to the mentioned four main factors, deep thermal fluids and overpressure retardation may also affect the ASDL (McTavish, 1998; Hao et al., 2007; Fetter et al., 2019). Deep thermal fluids provide both fluids and a thermal source and can facilitate the maturation of organic matter. On the one hand, the conduction of thermal fluids through rocks and faults brings thermal energy to source rocks and promotes source rock maturation and hydrocarbon generation (Rullkötter et al., 1988). On the other hand, the $\mathrm{H}_{2}$ brought by the deep fluids can considerably improve the hydrocarbon generation rate through the kerogen hydrogenation process (Zhu et al., 2017). Consequently, compared with unaffected source rocks, source rocks influenced by deep thermal fluids may 
(a)

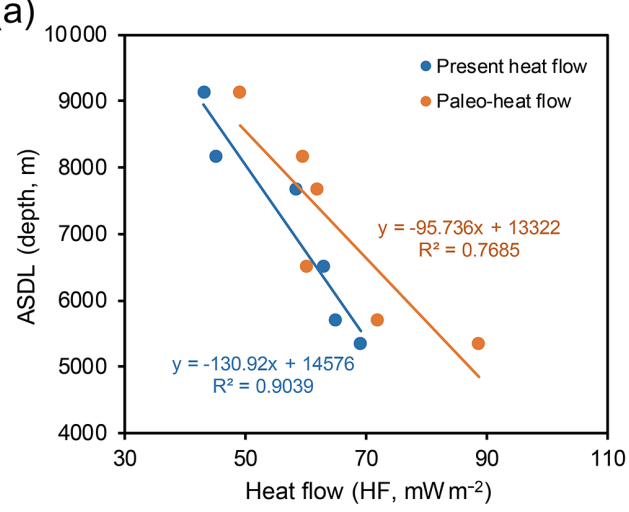

(b)

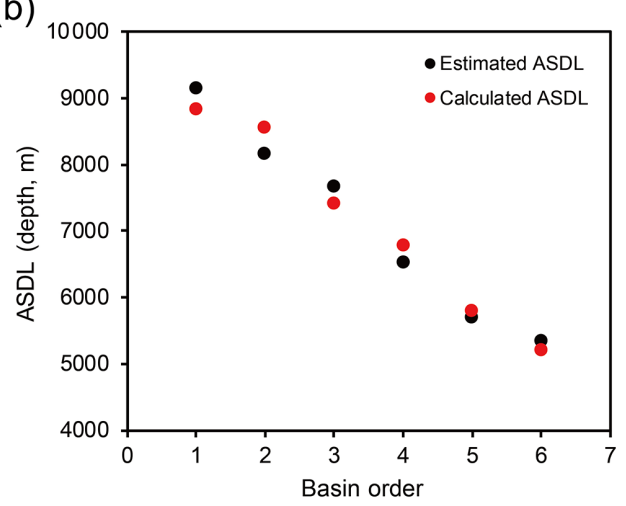

Figure 5. The quantitative relationships among the ASDL, heat flow, and kerogen type for the six basins. (a) Relationship between ASDLs and heat flows. (b) The comparison of the modeled depths through Eq. (1) and estimated depths of the ASDLs. Basin order: 1 - Tarim Basin; 2 - Junggar Basin; 3 - Sichuan Basin; 4 - Ordos Basin; 5 - Bohai Bay Basin; 6 - Songliao Basin.

(a)

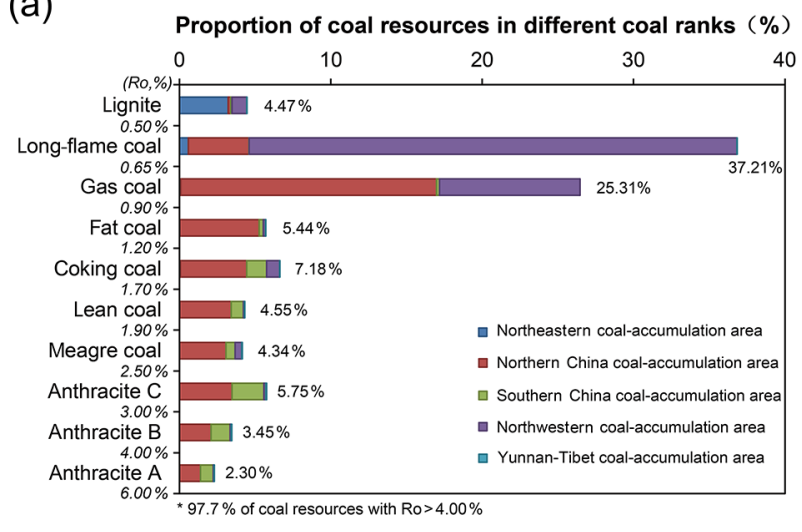

(b)

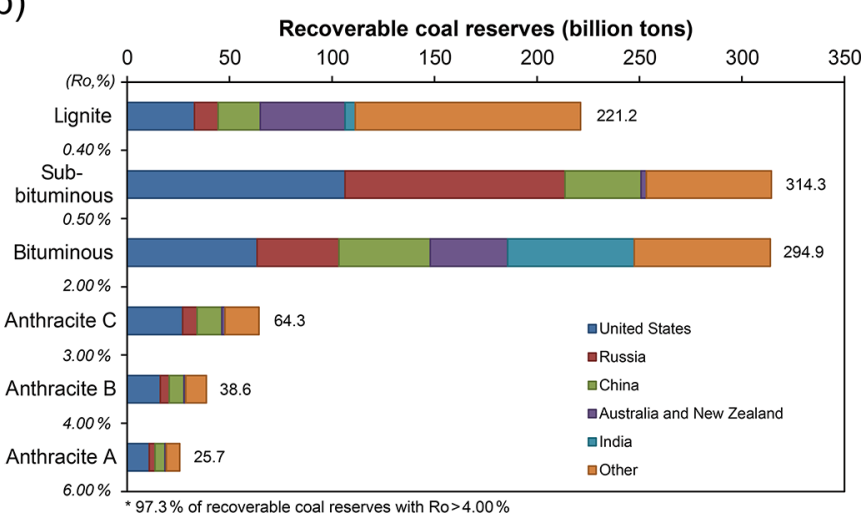

Figure 6. The variation in proven coal reserves with coal ranks in China and in the world. (a) The proportion of proven coal reserves with different coal ranks in China (data from CCRR, 1996; CNACG, 2016). The coal ranks are classified according to the Chinese standard, and the coal-accumulation area is shown in Fig. 1. (b) The recoverable coal reserves with different coal ranks around the word (data from Conti et al., 2016). The coal ranks are classified according to international standards. The proven coal reserves of anthracite $\mathrm{C}, \mathrm{B}$, and $\mathrm{A}$ are projected according to their variation trends.

have shallower ASDLs. In terms of overpressure retardation, an overpressure on source rocks can retard the thermal evolution of hydrogen-rich kerogen and/or the thermal cracking of hydrocarbons (McTavish, 1998; Hao et al., 2007). As a result, source rocks influenced by overpressure retardation have deeper ASDLs. It is worth noting that the thermal maturity corresponding to ASDL remains the same, no matter whether the ASDL becomes deeper or shallower. Namely, a source rock will reach ASDL when its Ro increases to $3.5 \% \pm 0.5 \%$ and its hydrocarbon generation potential is depleted. Therefore, we argue that the thermal maturity of organic matter is more suitable for characterizing ASDL than depth.

\subsection{Quantitative relationship between the ASDL and heat flow and organic matter type}

According to the analysis in the previous section, heat flow and organic matter type act as the two main factors controlling ASDLs. In this section, a quantitative relationship is further established by statistics using the software Origin 2019. We first analyzed the depths of ASDLs as a function of heat flow with a linear model. The ASDL inputted in the model for each basin is the average depth obtained from various geochemical indicators. The heat flow utilized in the model is the average of present heat flow values measured at different locations in each basin (Table 1). A strong negative correlation is observed between the ASDLs and the present heat flows with a coefficient larger than 0.9 (Fig. 5a), indicating that high heat flow very likely leads to a shallow ASDL. Considering that the heat flow values of a sedimentary basin vary with geologic time, the average heat flow since the de- 


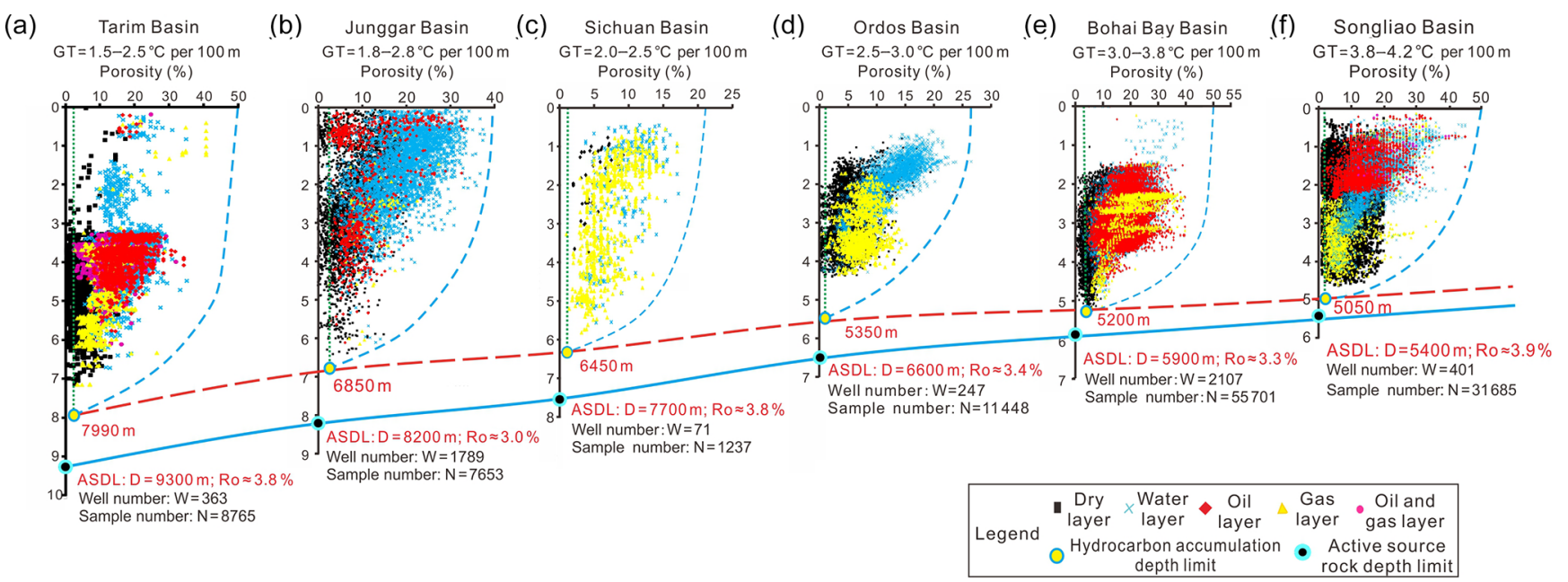

Figure 7. Hydrocarbon drilling results in the six representative petroliferous basins of China to show their relationships with the ASDLs and the HADLs. The results include 116489 samples of target layers from 4978 exploration wells in China. The blue dashed line represents the evolution of porosity with depth. Its intercept with the line of $2 \%$ porosity marks the HADL. The ASDL of each basin shown in this figure is represented by the value obtained from hydrocarbon generation potential index (" $S_{1}+S_{2}$ " / TOC) of each basin. From left to right: (a) Tarim Basin. (b) Junggar Basin. (c) Sichuan Basin. (d) Ordos Basin. (e) Bohai Bay Basin. (f) Songliao Basin. It is clear that the HADLs are always above the ASDLs.
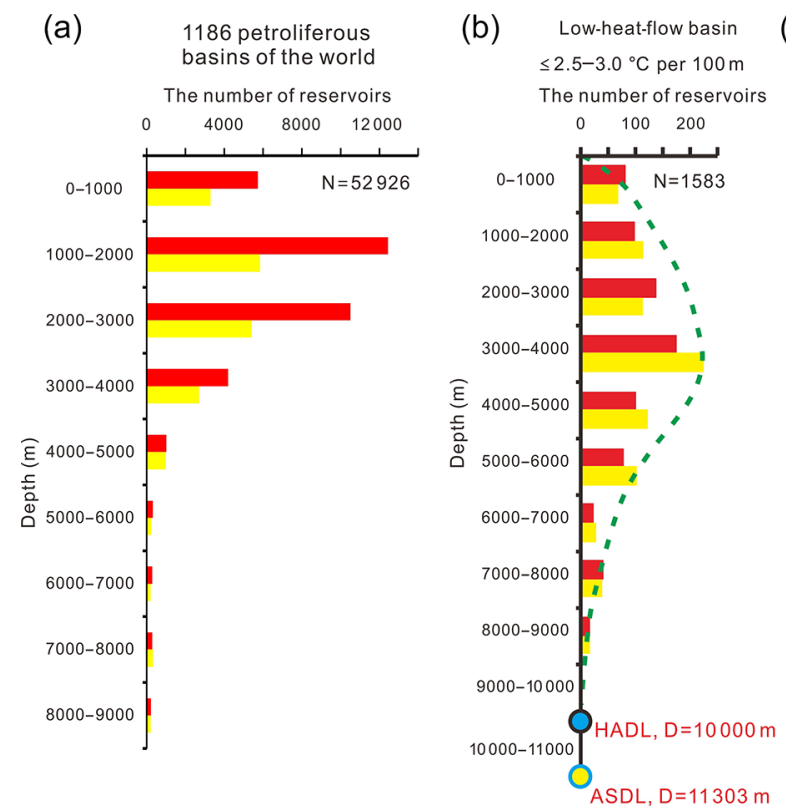
(c) Relative low-heat-flow basin

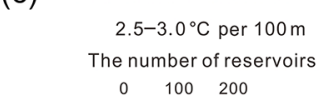
(d) Relative high-heat-flow basin $3.0-3.5^{\circ} \mathrm{C}$ per $100 \mathrm{~m}$ The number of reservoirs $0 \quad 100 \quad 200$
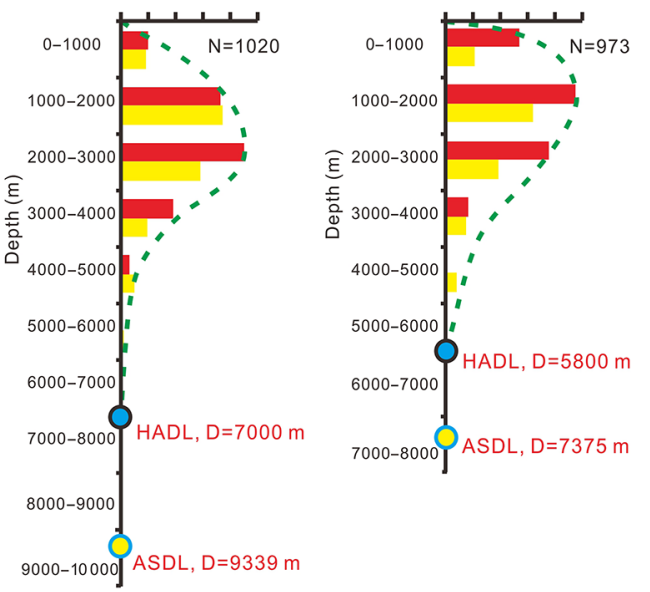

(e) High-heat-flow basin

s
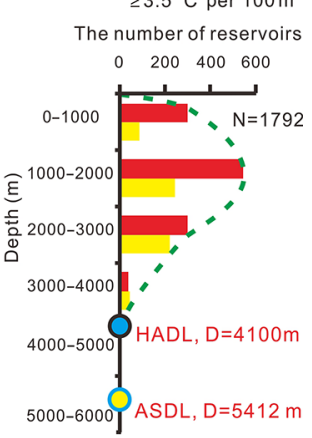

Figure 8. The vertical distribution of numbers of discovered hydrocarbon reservoirs and their relationships with ASDLs and HADLs in the worldwide 1186 petroliferous basins. (a) Summation of proven reservoirs in the 1186 basins. (b) Low-heat-flow basins $\left(<25 \mathrm{~mW} \mathrm{~m}^{-2}\right.$ ). (c) Relative low-heat-flow basins $\left(25-40 \mathrm{~mW} \mathrm{~m}^{-2}\right)$. (d) Relative high-heat-flow basins $\left(40-55 \mathrm{~mW} \mathrm{~m}^{-2}\right)$. (e) High-heat-flow basins $(55-$ $70 \mathrm{~mW} \mathrm{~m}^{-2}$ ). The intercept of the green dashed line on the vertical axis marks the HADL. The ASDL, shown in this figure, of each kind of basin with different heat flow is predicted by using the equation shown in Fig. 5.

position of source rocks was further employed. As shown in Fig. 5a, the ASDLs also present an obvious negative correlation with average paleo-heat flows. This implies that the paleo-heat flows and present heat flows both contribute to the thermal maturation of source rocks and therefore play an im- portant role in controlling the ASDLs. We mainly utilize the present heat flow values in the following discussion, mainly because the correlation $(R=0.90)$ between the ASDL and present heat flow is much higher than that $(R=0.77)$ between the ASDL and the average value of paleo-heat flow. 
It is also observed that the maximum burial depth of oilbearing targets in most basins mainly corresponds to the maximum temperature under the current heat flow. ASDLs for basins of different current heat flows range between 3000 and $16000 \mathrm{~m}$. Generally, ASDLs are less than $6000 \mathrm{~m}$ in basins with high heat flow $\left(>70 \mathrm{~mW} \mathrm{~m}^{-2}\right)$ and are greater than $9000 \mathrm{~m}$ in basins with low heat flow $\left(<40 \mathrm{~mW} \mathrm{~m}^{-2}\right)$. Given that the ASDL is also influenced by organic matter type, we further analyzed the effects of organic matter type on ASDL by adding the hydrogen index (HI), an indicator of organic matter type, to the linear model. The HI is a quantitative proxy for the characterization of kerogen types and is easily obtained through Rock-Eval analysis. Numerous studies on source rock evaluation from the scientific community have proven the reliability of the HI. Furthermore, the HI has been widely chosen as the indicator of kerogen type in professional software, such as PetroMod, which is often used by the industrial community. To quantify the influence of organic matter types on ASDLs, the hydrogen index values of $600 \mathrm{mg} \mathrm{HC}$ per g TOC, $450 \mathrm{mg}$ HC per g TOC, $525 \mathrm{mg} \mathrm{HC}$ per g TOC, $250 \mathrm{mg}$ HC per g TOC, and $125 \mathrm{mg} \mathrm{HC}$ per $\mathrm{g}$ TOC are assigned to type I, I-II, II, II-III, and III kerogens, respectively. The following equation is then deduced:

$\mathrm{ASDL}=16448-3.61 \cdot \mathrm{HI}-139.46 \cdot \mathrm{HF}$,

where the ASDL is the active source rock depth limit (in meters), the $\mathrm{HI}$ is the hydrogen index value of the major source rocks in a basin (in $\mathrm{mg} \mathrm{HC}$ per $\mathrm{g}$ TOC), and HF is the present average heat flow value of a basin (in $\mathrm{mW} \mathrm{m}^{-2}$ ).

Although Eq. (1) shows a high correlation coefficient of 0.96 (Fig. 5b), this equation, instead of being utilized to precisely predict the ASDL of a basin, is only presented to confirm the existence of a relationship among the ASDL, heat flow, and organic matter type because of the following reasons. First, the variation in organic matter types in our study is relatively small (Table 1), and, therefore, the hydrogen index values utilized to deduce Eq. (1) show small variations, which can introduce uncertainties to some extent. Second, as mentioned in the above section, the ASDL is not only influenced by the heat flow and organic matter type but also by the stratigraphic age and tectonic uplift. Equation (1), having not included all the four major factors, is therefore not sufficient to predict the precise ASDL of a basin. Setting up a model with four independent variables, however, is difficult and impossible with our database of six basins. Construction of a complete and precise model or equation needs help from the scientific community to enrich the database. We suggest that basin modeling and other integrated analysis methods should be applied if readers want to predict the depth of the ASDL in a basin without enough geological and geochemical data. The quantitative relationship indicated in Eq. (1) provides preliminary insights into the geological basis and boundary condition for the prediction of fossil fuel distribution in the basins and helps the evaluation of hydrocarbon potential. (a)
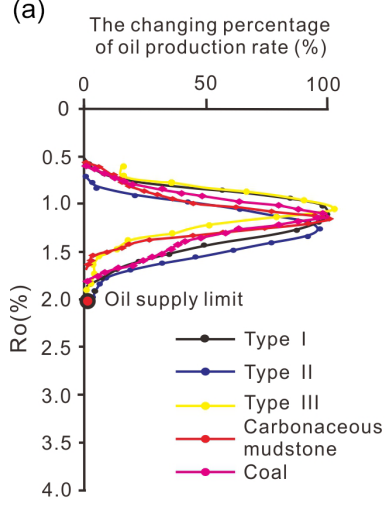

(b)
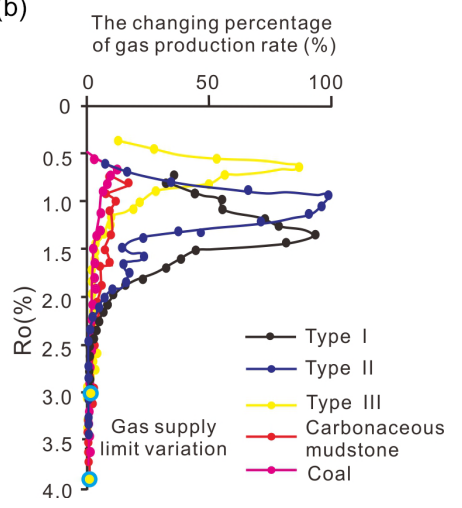

Figure 9. Investigation of ASDLs for different hydrocarbon types by high-temperature and high-pressure pyrolysis simulation. (a) The variation in oil production rate with Ro and identification of ASDLo. (b) The variation in gas production rate with Ro and identification of ASDLg.

\subsection{ASDL controlling the vertical distribution of fossil fuel resources}

Fossil fuel resources, formed from organic matter over the course of millions of years, are currently the primary energy sources in the world. Oil and gas are the products during the evolution of organic matter, while coal is the residue of organic matter. The ASDL is the critical condition or the dynamical boundary at which oil and gas expulsion ends. It controls the formation and distribution of all economical hydrocarbon reservoirs. Once the burial depth of organic matter exceeds the ASDL, the hydrocarbons are no longer generated from the source rocks, and the coal evolves into graphite, losing its industrial value as fuel. Theoretically, the ASDL represents the maximum depth of the formation and distribution of fossil fuels. According to Fig. 6, approximately $97.7 \%$ of coal resources in China and $97.3 \%$ of recoverable coal reserves around the world are distributed above ASDLs, corresponding to an Ro of $4.0 \%$ (CCRR, 1996; CNACG, 2016; Conti et al., 2016). Therefore, the ASDL represents the maximum depth of hydrocarbon reservoir distribution, including oil, gas, and coal.

This study also analyzed the drilling results for 116489 samples of target layers from 4978 exploration wells in the six basins in China (Fig. 7). The data show that all the reservoirs in the six basins were distributed above the ASDLs, reflecting the control of the ASDL on the formation and distribution of hydrocarbon reservoirs. The probability of drilling commercial oil and gas reservoirs decreases with increasing burial depth, whereas the probability of drilling dry layers increases. At some depth, the probability of drilling oil or gas reservoirs decreases to zero, and this depth is regarded as the hydrocarbon accumulation depth limit (HADL). Similar to the ASDL, the HADL is also influenced by many factors, such as the hydrocarbon phases, the geothermal field, 


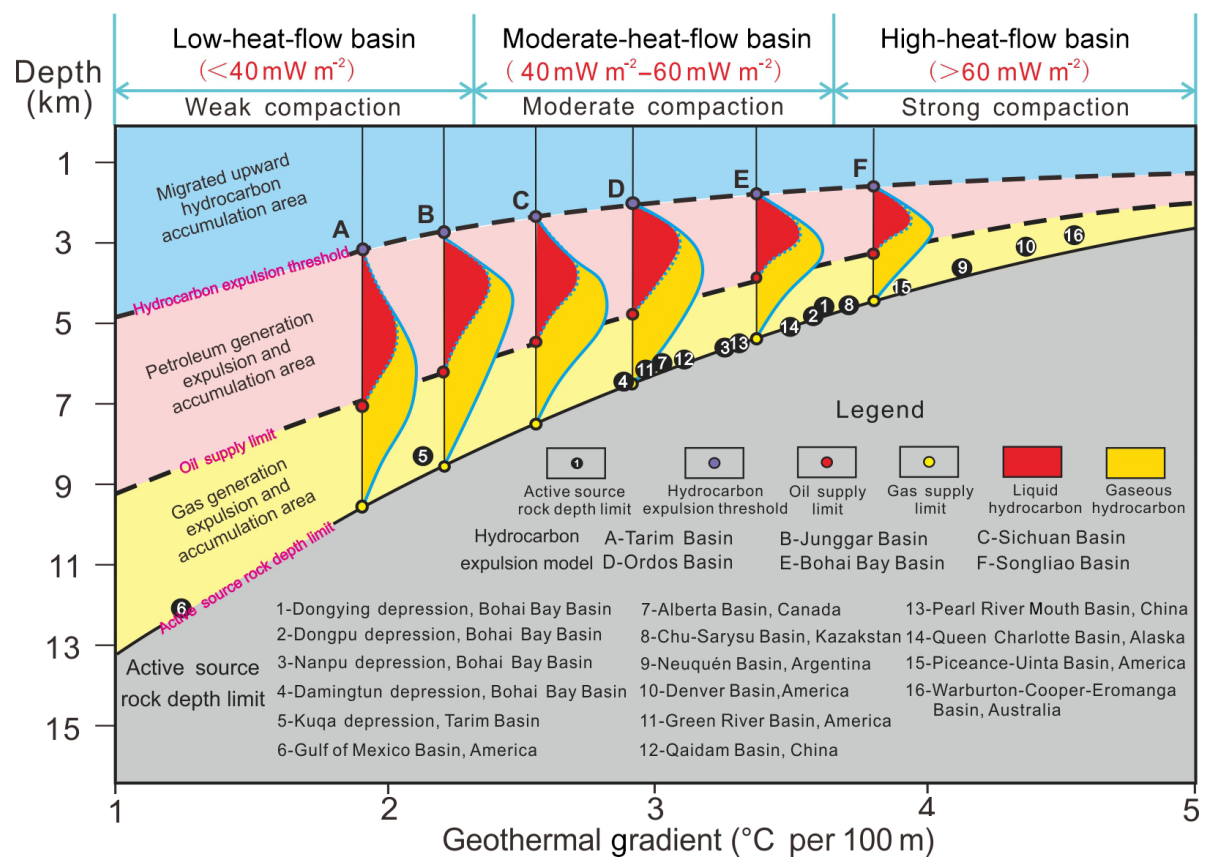

Figure 10. The pattern of ASDLs on the formation and distribution of hydrocarbon reservoirs in petroliferous basins. The upper blue area is favorable for the formation and distribution of conventional oil and gas resources, and hydrocarbons come from the underlying source rocks. The middle pink area is favorable for oil and gas generation, migration, and accumulation from source rocks in this area, mainly from conventional oil and gas reservoirs. The lower yellow area is favorable for natural gas generation, migration, and accumulation from source rocks, mainly from tight unconventional gas reservoirs.

and the strata age and lithology of the reservoir, and will be discussed in other papers. Here, we just focus on the relationship between the HADL and ASDL. The HADLs of the six basins are marked in Fig. 7 as yellow dots and connected by a dashed red line. The ASDLs deduced from (" $S_{1}+S_{2}$ ") / TOC (Table 2) are also marked in Fig. 7 and connected with a solid blue line. Meanwhile, according to the vertical distribution characteristics of proven hydrocarbon reserves, it is observed that all proven hydrocarbon reserves in the six representative basins are controlled by the HADLs which are above the ASDLs (Figs. 7 and S6). This means that the HADL in a basin is controlled by its ASDL and should always be above the ASDL. The currently discovered natural gas hydrate around the world is also distributed in fields with active source rocks (Dai et al., 2017). We further extended the research to 52926 reservoirs in 1186 basins around the world recorded in IHS (2010). The HADL for each basin was derived from the actual reservoir depth data in IHS (2010) using the same method as described in the previous paragraph (Fig. 7), and the results are shown in Fig. 8. The ASDL for each basin is assumed to be at an Ro of $3.5 \%$, and the corresponding depth is obtained from the documented heat flow of that basin. We found that the HADLs (represented as depth) are universally above the ASDLs for all the basins.

Hydrocarbons are generally classified into two big categories as natural gas and liquid petroleum, which have distinct physical properties. By definition, the ASDL marks the end of generation of any hydrocarbon from source rocks, but this concept can be modified to incorporate the two types of hydrocarbons. Therefore, two ASDLs are introduced, including the ASDLg for gas and ASDLo for oil. The ASDLo indicates that source rocks can no longer generate oil and is called the oil supply limit. The ASDLg indicates that source rocks can no longer generate gas and is called the gas supply limit. Hydrocarbons generated and exposed by source rocks of low thermal maturities are mainly liquid oil and gaseous hydrocarbons. The gaseous hydrocarbons become the dominant components with nearly no liquid oil when the thermal maturity is high. Therefore, theoretically speaking, the burial depth and thermal maturity corresponding to the ASDLo should be shallower than that of the ASDLg. To investigate the ASDLs for different fluids, the high-temperature (room temperature to $600{ }^{\circ} \mathrm{C}$ ) and high-pressure $(50 \mathrm{MPa})$ pyrolysis simulation experiments were conducted on immature or lowmaturity kerogens sampled from Junggar Basin in a closed system. According to the experiment results, source rocks reach the ASDLo at an Ro of about $2.0 \%$ (Fig. 9), and the same source rocks reach the ASDLg at an Ro of $3.0 \%$ to $4.0 \%$.

Besides this, Pang et al. (2005) proposed the concept of the HET, which marks the starting point of source rocks expelling hydrocarbons at a certain depth. The HET, ASDLo, and ASDLg divide a basin into three regions in the vertical direction, and they control the types of hydrocarbon reser- 
voirs and their distributions (Fig. 10). The upper field (blue area in Fig. 10) is favorable for hydrocarbons migrating upward to form conventional reservoirs in traps, and the source rocks in this field are dominantly immature and/or less mature. The middle field (pink area in Fig. 10) is favorable for source rocks to generate, expel, and retain hydrocarbons to form various kinds of oil and gas reservoirs, and the source rocks in this field supply hydrocarbons that may migrate into the upper area. The lower field (yellow area in Fig. 10) is favorable for source rocks to generate, expel, and retain natural gas to form mainly unconventional resources. Figure 10 includes a series of low-heat-flow to high-heat-flow basins in the world and illustrates the effect of heat flow on the distribution of HETs and ASDLs. The characteristics of hydrocarbon generation and reservoir distribution differ among these basins due to their different geological conditions and tectonic settings.

\section{Data availability}

The datasets can be accessed at: https://doi.org/10.1594/PANGAEA.900865 (Pang et al., 2019).

\section{Conclusions}

1. The ASDL is the maximum burial depth for source rocks to generate and expel hydrocarbons from thermal cracking of kerogen. The ASDL marks the depletion of hydrocarbon generation potentials of source rocks, and it commonly exists in petroliferous basins. We found that the thermal maturity of $3.5 \%$ can be regarded as the identification criterion of the ASDL in general geological conditions.

2. The ASDLs of all basins around the world vary from 3000 to $16000 \mathrm{~m}$, and this variation is mainly caused by heat flow, kerogen type, age of source rock strata, and tectonic movement. The ASDL of a basin is deep when the basin's heat flow is low and/or the source rock kerogen is oil-prone. Tectonic uplift of source rock strata can significantly shallow the ASDL.

3. All types of fossil fuel resources, including coal and conventional and unconventional oil and gas, are formed and distributed above the ASDLs. A basin can be vertically divided into three fields by the HET, the oil supply limit, and the gas supply limit. The three fields are favorable for different types of reservoirs.

Supplement. The supplement related to this article is available online at: https://doi.org/10.5194/essd-12-577-2020-supplement.
Author contributions. XP proposed the concept of the ASDL, designed the study, and led the writing of the paper in close collaboration with $\mathrm{KZ}$ and JC. The data used in this study were collected by YW and BL. CJ helped collect the data and explained the significance of the ASDL. KZ investigated the influence of the geothermal gradient on the ASDL. ML studied the influence of organic matter type on the ASDL. JP illustrated the mechanism of depletion of hydrocarbon generation potential. All authors reviewed and approved the paper.

Competing interests. The authors declare that they have no conflict of interest.

Acknowledgements. The authors thank the support from the Application Foundation Research Program of PetroChina, Sinopec, and the CNOOC. We also thank the Tarim Oilfield Company, Xinjiang Oilfield Company, Liaohe Oilfield Company, Southwest Oilfield Company, Daqing Oilfield Company of PetroChina, Shengli Oilfield Company, and Zhongyuan Oilfield Company of Sinopec for providing data and permission to publish the results. We acknowledge Yong Qin for assistance in the process of collecting data. Changrong $\mathrm{Li}$ is also appreciated for his kind help in the revision of the paper.

Financial support. This research has been supported by the National Basic Research Program of China (grant no. 2006CB202300; 2011CB2011).

Review statement. This paper was edited by Attila Demény and reviewed by György Pogácsás and Ludden John.

\section{References}

Behar, F., de Barros Penteado, H. L., Lorant, F., and Budzinski, H.: Study of biodegradation processes along the Carnaubais trend, Potiguar Basin (Brazil) - Part 1, Org. Geochem., 37, 1042-1051, https://doi.org/10.1016/j.orggeochem.2006.05.009, 2006.

Cao, J., Zhang, Y., Hu, W., Yao, S., Wang, X., Zhang, Y., and Tang, Y.: The Permian hybrid petroleum system in the northwest margin of the Junggar Basin, northwest China, Mar. Petrol. Geol., 22, 331-349, https://doi.org/10.1016/j.marpetgeo.2005.01.005, 2005.

CCRR (Editorial committee of China coal resources report) Comparison of coal resources between China and major coalproducing countries, China Coal, 7, 68-71, 1996.

Chen, Z., Zha, M., Liu, K., Zhang, Y., Yang, D., Tang, Y., Tang, Y., Wu, K., and Chen, Y.: Origin and accumulation mechanisms of petroleum in the Carboniferous volcanic rocks of the Kebai Fault zone, Western Junggar Basin, China, J. Asian Earth Sci., 127, 170-196, https://doi.org/10.1016/j.jseaes.2016.06.002, 2016.

CNACG (China National Administration of Coal Geology) China occurrence regularity of coal resources and resource evaluation, Science Press, Beijing, China, 2016. 
Conti, J., Holtberg, P., Diefenderfer, J., LaRose, A., Turnure, J. T., and Westfall, L.: International energy outlook 2016 with projections to 2040 (No. DOE/EIA-0484, 2016), USDOE Energy Information Administration (EIA), Office of Energy Analysis, Washington, DC, US, https://doi.org/10.2172/1296780, 2016.

Dai, J. X., Ni, Y. Y., Huang, S. P., Peng, W. L., Han, W. X., Gong, D. Y., and Wei, W.: Genetic types of gas hydrates in China, Petrol. Explor. Dev., 44, 887-898, https://doi.org/10.1016/S18763804(17)30101-5, 2017.

Durand, B.: Kerogen: Insoluble organic matter from sedimentary rocks, Editions technip, Paris, France, 1980.

Dyman, T. S., Crovelli, R. A., Bartberger, C. E., and Takahashi, K. I.: Worldwide estimates of deep natural gas resources based on the US Geological Survey World Petroleum Assessment 2000, Natural Resources Research, 11, 207-218, https://doi.org/10.1023/A:1019860722244, 2002.

Espitalie, J., Deroo, G., and Marquis, F.: La pyrolyse Rock-Eval etses applications, Deuxièmepartie, Revue de l'Institutfrançais du Pétrole, 40, 755-784, https://doi.org/10.2516/ogst:1985045, 1985.

Fetter, N., Blichert-Toft, J., Ludden, J., Lepland, A., Borque, J. S., Greenhalgh, E., Garcia, B., Edwards, D., Télouk, P., and Albarède, F.: Lead isotopes as tracers of crude oil migration within deep crustal fluid systems, Earth Planet. Sc. Lett., 525, 115747, https://doi.org/10.1016/0146-6380(88)90237-9, 2019.

Gautier, D. L., Bird, K. J., Charpentier, R. R., Grantz, A., Houseknecht, D. W., Klett, T. R., More, T. E., Pitman, J. K., Schenk, C. J., Schuenemeyer, J. H., Sørensen, K., Tennyson, M. E., Valin, Z. C., and Wandrey, C. J.: Assessment of undiscovered oil and gas in the Arctic, Science, 324, 1175-1179, https://doi.org/10.1126/science.1169467, 2009.

Glasby, G. P.: Abiogenic origin of hydrocarbons: An historical overview, Resour. Geol., 56, 83-96, https://doi.org/10.1111/j.1751-3928.2006.tb00271.x, 2006.

Global, B. P.: BP statistical review of world energy June 2017, Relatório, Disponível em, available at: http://www.bp.com/en/global/corporate/energy-economics/ statistical-review-of-world-energy.html (last access: 7 March 2020), 2017.

Gold, T.: The Origin of Methane (and Oil) in the Crust of the Earth, USGS Professional Paper, 1570, 1-27, 1993.

Hao, F., Zou, H., Gong, Z., Yang, S., and Zeng, Z.: Hierarchies of overpressure retardation of organic matter maturation: Case studies from petroleum basins in China, AAPG Bulletin, 91, 14671498, https://doi.org/10.1306/05210705161, 2007.

Hayes, J. B.: Porosity evolution of sandstones related to vitrinite reflectance, Org. Geochem., 17, 117-129, https://doi.org/10.1016/0146-6380(91)90070-Z, 1991.

Höök, M., Bardi, U., Feng, L., and Pang, X.: Development of oil formation theories and their importance for peak oil, Mar. Petrol. Geol., 27, 1995-2004, https://doi.org/10.1016/j.marpetgeo.2010.06.005, 2010.

Hunt, J. M.: Petroleum geochemistry and geology, WH Freeman, New York, US, 2, 1-743, 1996.

IHS Energy Group: International petroleum exploration and production database, IHS Energy Group, Englewood, Colorado, 2010 .
Jia, C. Z., Pang, X. Q., and Jiang, F. J.: Research status and development directions of hydrocarbon resources in China, Petroleum Science Bulletin, 1, 2-23, 2016.

Jiang, F., Pang, X., Bai, J., Zhou, X., Li, J., and Guo, Y.: Comprehensive assessment of source rocks in the Bohai Sea area, eastern China, AAPG Bulletin, 100, 969-1002, https://doi.org/10.1306/02101613092, 2016.

Kenney, J. F., Kutcherov, V. A., Bendeliani, N. A., and Alekseev, V. A.: The evolution of multicomponent systems at high pressures: VI. The thermodynamic stability of the hydrogencarbon system: The genesis of hydrocarbons and the origin of petroleum, P. Natl. Acad. Sci. USA, 99, 10976-10981, https://doi.org/10.1073/pnas.172376899, 2002.

Magoon, L. B. and Dow, W. G.: The petroleum system, in: The petroleum system - From source to trap, edited by: Magoon, L. B. and Dow, W. G., American Association of Petroleum Geologists Memoir 60, 3-24, 1994

McTavish, R. A.: The role of overpressure in the retardation of organic matter maturation, J. Petrol. Geol., 21, 153-186, https://doi.org/10.1111/j.1747-5457.1998.tb00652.x, 1998.

Pang, X., Chen, Z., and Chen, F: Basic concept of hydrocarbon expulsion threshold and its research significance and application, Geoscience, 11, 510-521, 1997.

Pang, X., Li, S., Jin, Z., and Bai, G.: Quantitative assessment of hydrocarbon expulsion of petroleum systems in the Niuzhuang sag, Bohai Bay Basin, East China, Acta Geol. Sin.-Engl., 78, 615625, https://doi.org/10.1111/j.1755-6724.2004.tb00174.x, 2004.

Pang, X., Li, M., Li, S., and Jin, Z.: Geochemistry of petroleum systems in the Niuzhuang South Slope of Bohai Bay Basin: Part 3. Estimating hydrocarbon expulsion from the Shahejie formation, Org. Geochem., 36, 497-510, https://doi.org/10.1016/j.orggeochem.2004.12.001, 2005.

Pang, X. Q., Jia, C. Z., and Wang, W. Y.: Petroleum geology features and research developments of hydrocarbon accumulation in deep petroliferous basins, Pet. Sci., 12, 1-53, https://doi.org/10.1007/s12182-015-0014-0, 2015.

Pang, X. Q., Jia, C. Z., Zhang, K., Li, M. W., Wang, Y. W., Peng, J. W., Li, B. Y., and Chen, J. Q.: Geological and geochemical data of 13634 source rock samples from 1286 exploration wells and 116489 porosity data from target layers in the six petroliferous basins of China, PANGAEA, https://doi.org/10.1594/PANGAEA.900865, 2019.

Peng, J., Pang, X., Shi, H., Peng, H., and Xiao, S.: Hydrocarbongeneration potential of upper Eocene Enping Formation mudstones in the Huilu area, northern Pearl River Mouth Basin, South China Sea, AAPG Bulletin, 102, 1323-1342, https://doi.org/10.1306/0926171602417005, 2018.

Peters, K. E. and Cassa, M. R.: Applied source-rock geochemistry, in: The Petroleum System - From Source to Trap, edited by: Magoon, L. B. and Dow, W. G., American Association of Petroleum Geologists Memoir 60, 93-120, 1994.

Peters, K. E., Walters, C. C., and Moldowan, J. M.: The biomarker guide (Vol. 1), Cambridge University Press, Cambridge, UK, 2005.

Peters, K. E., Hackley, P. C., Thomas, J. J., and Pomerantz, A. E.: Suppression of vitrinite reflectance by bitumen generated from liptinite during hydrous pyrolysis of artificial source rock, Org. Geochem., 125, 220-228, https://doi.org/10.1016/j.orggeochem.2018.09.010, 2018. 
Ping, H., Chen, H., and Jia, G.: Petroleum accumulation in the deeply buried reservoirs in the northern Dongying Depression, Bohai Bay Basin, China: New insights from fluid inclusions, natural gas geochemistry, and 1-D basin modeling, Mar. Petrol. Geol., 80, 70-93, https://doi.org/10.1016/j.marpetgeo.2016.11.023, 2017.

Rullkötter, J., Leythaeuser, D., Horsfield, B., Littke, R., Mann, U., Müller, P. J., Schaefer, R. G., Schenk, H.-J., Schwochau, K., and Witte, E. G.: Organic matter maturation under the influence of a deep intrusive heat source: a natural experiment for quantitation of hydrocarbon generation and expulsion from a petroleum source rock (Toarcian shale, northern Germany), Org. Geochem., 13, 847-856, https://doi.org/10.1016/01466380(88)90237-9, 1988.

Selley, R. C. and Sonnenberg, S. A.: Elements of petroleum geology, Academic Press, San Diego, USA, 2014.

Tissot, B., Durand, B., Espitalie, J., and Combaz, A.: Influence of nature and diagenesis of organic matter in formation of petroleum, AAPG Bulletin, 58, 499506, https://doi.org/10.1306/83D90CEB-16C7-11D78645000102C1865D, 1974.

Tissot, B. P. and Welte, D. H.: Petroleum Formation and Occurrence, 1st edn., Springer, Berlin, 538 pp., 1978.

Transocean, Deepwater Horizon Drills World's Deepest Oil \& Gas Well: September 2, available at: https://web.archive.org/web/20100428004206/deepwater.com/ fw/main/IDeepwater-Horizon-i-Drills-Worlds-Deepest-Oil-andGas-Well-419C1.html?LayoutID=6 (last access: 22 June 2018), 2009.

Wang, C. S., Chang, E. Z., and Zhang, S. N.: Potential oil and gas-bearing basins of the QinghaiTibetan Plateau, China, Int. Geol. Rev., 39, 876-890, https://doi.org/10.1080/00206819709465307, 1997.

Wang, S., He, L., and Wang, J.: Thermal regime and petroleum systems in Junggar Basin, northwest China, Phys. Earth Planet. In., 126, 237-248, https://doi.org/10.1016/S0031-9201(01)00258-8, 2001.

Wang, T. G., Zhong, N. N., Wang, C. J., Zhu, Y. X., Liu, Y., and Song, D. F.: Source beds and oil entrapment-alteration histories of fossil-oil-reservoirs in the Xiamaling formation basal sandstone, Jibei depression, Petroleum Science Bulletin, 1, 24-37, https://doi.org/10.3969/j.issn.2096-1693.2016.01.002, 2016.
Wang, Y., Yang, R., Song, M., Lenhardt, N., Wang, X., Zhang, X., Yang, S., Wang, J., and Cao, H.: Characteristics, controls and geological models of hydrocarbon accumulation in the Carboniferous volcanic reservoirs of the Chunfeng Oilfield, Junggar Basin, northwestern China, Mar. Petrol. Geol., 94, 65-79, https://doi.org/10.1016/j.marpetgeo.2018.04.001, 2018.

Wu, S. X., Jin, Z. J., Tang, L. J., and Bai, Z. R.: Characteristics of Triassic petroleum systems in the Longmenshan foreland basin, Sichuan province, China, Acta Geol. Sin.-Engl., 82, 554-561, https://doi.org/10.1111/j.1755-6724.2008.tb00606.x, 2008.

Xiao, X. M., Zhao, B. Q., Thu, Z. L., Song, Z. G., and Wilkins, R. W. T.: Upper Paleozoic petroleum system, Ordos Basin, China, Mar. Petrol. Geol., 22, 945-963, https://doi.org/10.1016/j.marpetgeo.2005.04.001, 2005.

Zhou, J. and Pang, X. Q.: A method for calculating the quantity of hydrocarbon generation and expulsion, Petrol. Explor. Dev.+, 29, 24-27, 2002.

Zhou, Y. and Littke, R.: Numerical simulation of the thermal maturation, oil generation and migration in the Songliao Basin, Northeastern China, Mar. Petrol. Geol., 16, 771-792, https://doi.org/10.1016/S0264-8172(99)00043-4, 1999.

Zhu, C., Hu, S., Qiu, N., Rao, S., and Yuan, Y.: The thermal history of the Sichuan Basin, SW China: Evidence from the deep boreholes, Sci. China Earth Sci., 59, 70-82, https://doi.org/10.1007/s11430-015-5116-4, 2016.

Zhu, D., Liu, Q., Jin, Z., Meng, Q., and Hu, W.: Effects of deep fluids on hydrocarbon generation and accumulation in Chinese petroliferous basins, Acta Geol. Sin.-Engl., 91, 301-319, https://doi.org/10.1111/1755-6724.13079, 2017.

Zhu, G., Cao, Y., Yan, L., Yang, H., Sun, C., Zhang, Z., Li, T., and Chen, Y.: Potential and favorable areas of petroleum exploration of ultra-deep marine strata more than $8000 \mathrm{~m}$ deep in the Tarim Basin, Northwest China, Journal of Natural Gas Geoscience, 3, 321-337, https://doi.org/10.1016/j.jnggs.2018.12.002, 2018.

Zhu, Y. M.: Coal Mine Geology, China University of Mining and Technology Press, Xuzhou, China, 2011. 